Ulrich Sommer • Frank Sommer • Barbara Santer •

Eckart Zöllner · Klaus Jürgens · Colleen Jamieson •

Maarten Boersma $\cdot$ Klaus Gocke

\title{
Daphnia versus copepod impact on summer phytoplankton: functional compensation at both trophic levels
}

Received: 16 April 2002 / Accepted: 10 February 2003 / Published online: 28 March 2003

(C) Springer-Verlag 2003

\begin{abstract}
Here we report on a mesocom study performed to compare the top-down impact of microphagous and macrophagous zooplankton on phytoplankton. We exposed a species-rich, summer phytoplankton assemblage from the mesotrophic Lake Schöhsee (Germany) to logarithmically scaled abundance gradients of the microphagous cladoceran Daphnia hyalina $\times$ galeata and of a macrophagous copepod assemblage. Total phytoplankton biomass, chlorophyll a and primary production showed only a weak or even insignificant response to zooplankton density in both gradients. In contrast to the weak responses of bulk parameters, both zooplankton groups exerted a strong and contrasting influence on the phytoplankton species composition. The copepods suppressed large phytoplankton, while nanoplanktonic algae increased with increasing copepod density. Daphnia suppressed small algae, while larger species compensated in terms of biomass for the losses. Autotrophic picoplankton declined with zooplankton density in both gradients. Gelatinous, colonial algae were fostered by both zooplankton functional groups, while medium-sized (ca. 3,000 $\mathrm{mm}^{3}$ ), non-gelatinous algae were suppressed by both. The impact of a functionally mixed zooplankton assemblage became evident when Daphnia began to invade and grow in copepod mesocosms after ca. 10 days. Contrary to the impact of a single functional group, the combined impact of both zooplankton groups led to a substantial decline in total phytoplankton biomass.
\end{abstract}

\footnotetext{
U. Sommer $(-$ F. Sommer · K. Gocke

Institut für Meereskunde,

Düsternbrooker Weg 20, 24105 Kiel, Germany

e-mail: usommer@ifm.uni-kiel.de

B. Santer · E. Zöllner · K. Jürgens · C. Jamieson

Max-Planck-Institut für Limnologie,

Postfach 165, 24302 Plön, Germany

M. Boersma

Alfred-Wegener-Institut, BAH,

Postfach 180, 27498 Helgoland, Germany
}

Keywords Phytopankton - Zooplankton · Copepoda . Cladocera · Top-down-control

\section{Introduction}

Since Hairston et al. (1960) proposed their famous "green world" hypothesis, there has been controversy surrounding if and to what extent herbivores could control primary producers. The green world hypothesis (dominance of community biomass by plants) has either been explained by successful plant defence against herbivory (the dominant terrestrial paradigm) or by predator control of herbivores (the dominant limnological paradigm; Shapiro and Wright 1984; Carpenter et al. 1985). In a recent review, Pace et al. (1999) found examples for both from all kinds of ecosystems. It is a general feature of the plantdefence hypothesis that herbivores should be able to control plant species composition but not total plant biomass, because plants with well-developed defence strategies would compensate for the losses of the less defensive ones (Power 1992; Strong 1992).

Here we report on a field experiment, where the primary producer level was represented by lake phytoplankton and the consumer level by either the cladoceran Daphnia or a mixed assemblage of copepods. Although we had planned to study only the impact of single zooplankton functional groups, contamination of the copepod treatments with Daphnia provided the opportunity of comparing the impact of a single functional group with that of two functional groups on phytoplankton.

Cladocerans and copepods are the most important components of crustacean zooplankton in fresh waters and contribute significantly to grazing pressure on phytoplankton and Protozoa. Significant top-down effects on phytoplankton, including order-of-magnitude reductions of phytoplankton biomass after the spring bloom ("clear water phase"), have been reported for zooplankton dominated by the cladoceran Daphnia spp. in lakes (Lampert 1978, 1988; Sommer et al. 1986) and for copepod-dominated zooplankton in the sea (Bautista et al. 
1992). While it is commonplace to regard Daphnia as second trophic level and cyclopoid copepods as third trophic level organisms, the trophic level of calanoid copepods has become a matter of debate during the last years. In fact, both Daphnia and calanoid copepods are probably best characterised as omnivores with different, but widely overlapping food size spectra (Adrian and Schneider-Olt 1999; Burns and Schallenberg 1996; Geller and Müller 1981; Gliwicz 1980; Kleppel 1993; Sommer et al. 2000; Sommer and Stibor 2002; Stoecker and Capuzzo 1990). In addition to size, copepod feeding selectivity is also determined by chemical food quality (DeMott 1986, 1988) which might spare toxic or otherwise chemically unsuitable algae from being grazed, even if they are of the appropriate size. Gelatinous coverings are considered to function as protection against any kind of zooplankton grazing (Porter 1976; Sterner 1989).

A previous report on this study (Sommer et al. 2001) concentrated on the response of phytoplankton size classes and those individual phytoplankton species which can be counted by Utermöhl's (1958) inverted microscope method $(>3 \mu \mathrm{m})$. Here, we provide a more complete report of the experimental results, including the response of Protozoa and picoplankton, the time course of phytoplankton and zooplankton abundances and the aggregated response of phytoplankton productivity and biomass.

\section{Materials and methods}

Mesocosms

We installed 24 transparent polyethylene enclosures of $3.4 \mathrm{~m}^{3}$ volume and $3.2 \mathrm{~m}$ depth in moderately nutrient rich lake Schöhsee (northern Germany). The top $2 \mathrm{~m}$ of the enclosures was cylindrical, while the lower part was funnel shaped and ended in a tube to permit the sampling of freshly produced sediment. Two days before the addition of zooplankton, mesocosms were filled by lake water sieved through a 50- $\mu \mathrm{m}$ plankton gauze in order to remove mesozooplankton. Mesocosms were fertilised with phosphate in order to assure a balanced total N:total P ratio (Redfield ratio 16:1, in this study $34.86 \mu \mathrm{M} \mathrm{N}$ to $2.18 \mu \mathrm{M} \mathrm{P}$ ). On 9 August 2000 (hereafter called day 1), logarithmically scaled gradients of zooplankton density were established by adding zooplankton to the bags. Daphnia hyalina $\times$ galeata originated from stock cultures of the Max-Planck-Institute of Limnology, Plön, and copepods were collected with a plankton net from the lake. Cladocerans were removed from copepod catches by intense bubbling with air for $7 \mathrm{~h}$. The inoculum of Daphnia comprised the entire size spectrum from neonates to the largest adults $(0.8-2.4 \mathrm{~mm})$ while the copepod size spectrum ranged from early copepodid stages to adults (0.4$1.5 \mathrm{~mm}$ ). The cladoceran gradient consisted of seeding densities of $1.25,2.5,5,10,20,40$ individuals $1^{-1}$, the copepod gradient consisted of seeding densities of $5,10,20,40,80,160$ individuals $1^{-1}$. Each treatment was replicated twice, except for the lowest zooplankton densities of each gradient. Two enclosures received no zooplankton additions and served as controls. The seeding densities were made up in order to produce similar ranges of zooplankton biomass in both gradients. The basis for assuming one Daphnia to be the equivalent of four copepods was derived from the following data: Daphnia hyalina mean dry mass $(17 \mu \mathrm{g})$ from stock cultures (Santer 1990), copepods: $4 \mu \mathrm{g}$ calculated from Eudiaptomus mean length (Kiefer 1978) and a widely used length-weight regression (Bottrell et al. 1976) . Maximal seeding densities of each gradient are about double those of the seasonal abundance maxima in the Schöhsee (Fussmann 1996).
Phytoplankton and ciliate counts and biomass

Phytoplankton samples were taken at 2- to 4-day intervals immediately after mixing the content of the enclosures. Ciliates and phytoplankton species $>3 \mu \mathrm{m}$ were counted according to Utermöhl's (1958) inverted microscope technique (for details see Sommer et al. 2001). Ciliates were not distinguished taxonomically but assigned to three size classes $(<20 \mu \mathrm{m}, 20-40 \mu \mathrm{m},>40 \mu \mathrm{m}$ cell length).

Phytoplankton biomass was estimated as biovolume which was calculated according to appropriate geometric models (Hillebrand et al. 1999) after microscopic measurement of at least 20 individuals per taxon. Ciliate biomass was calculated according to the equation for rotational ellipsoids with the radius being $2 / 3$ of the longer axis and assuming a cell length of 15,30 , and $60 \mu \mathrm{m}$ for the three size classes.

Picoplankton and heterotrophic nanoflagellate counts and biomass

Samples for counts of picoplankton and nanoflagellates were preserved in formalin (final concentration $2 \%$ ) and stored at $4{ }^{\circ} \mathrm{C}$ until further processing (usually within the next $24 \mathrm{~h}$ ). Onemillilitre subsamples were filtered onto black polycarbonate filters (25 mm, pore size $0.2 \mu \mathrm{m}$; Millipore) and stained with 4,6diamidino-2-phenylindole (final concentration $100 \mu \mathrm{g} \mathrm{ml}^{-1}$ ) (Porter and Feig 1980). The filters were immediately embedded on a slide and frozen for later counting of bacteria, cyanobacteria and flagellates under an epifluorescence microscope (Zeiss Axiophot 2). Around 300 Synechococcus cells were counted in randomly chosen filter sections at $1,250 \times$ magnification. Nanoflagellates were counted by screening transects $(5-25 \mathrm{~mm})$ across the filter and sized by use of an ocular grid. Heterotrophic flagellates were distinguished from autotrophic ones by checking for chlorophyll a autofluorescence under blue light excitation.

\section{Mesozooplankton counts}

Zooplankton was sampled on days 4, 9, 13, 17, and 20 by towing a 50- $\mu$ m-mesh Apstein net with a top cowl with $9 \mathrm{~cm}$ aperture diameter from a depth of $3 \mathrm{~m}$ to the surface. On day 4, mixing of the enclosures prior to sampling was inefficient and most of the animals remained near the lower end of the bottom funnel. Therefore, data from this day were excluded from analyses because of undersampling. Zooplankton were fixed with $70 \%$ methanol and counted under a dissecting microscope.

\section{Primary production}

Primary production was measured by the ${ }^{14} \mathrm{C}$ method according to Steemann-Nielsen (1952) on days 8 and $10 . \mathrm{NaH}^{14} \mathrm{CO}_{3}(4 \mu \mathrm{Ci})$ was added to three clear polycarbonate vials filled with water from each enclosure after thorough mixing. One vial served as a dark sample while two were incubated for $3.5 \mathrm{~h}$ in a slowly rotating incubator with radially arranged neutral grey filters ("turbulence incubator"; K. Gocke and J. Lenz, submitted). The incubator was exposed to full daylight and cooled to ambient temperatures by a through-flow of lake water. The filters permitted the transmission of exponentially decreasing light, thus simulating the circulation of algae through a mixed water column. The daily photosynthetic rate was calculated by multiplying the rate during the incubation period with the ratio of the daily light dose to the light dose during incubation. The specific activity was expressed as assimilation index (daily PPR/chlorophyll a) and as production/biomass (P/B) ratio. For that purpose, total biovolume values were converted into algal $\mathrm{C}$, assuming $1 \mu^{3}$ biovolume being equivalent to $0.1 \mathrm{pg} \mathrm{C}$ (Nalewajko 1966).

\section{Statistical evaluation}

On day 9, when zooplankton gradients were still almost uncontaminated, phytoplankton-zooplankton relationships were analysed by separate regression analysis for each gradient. Because of the logarithmic scaling of the gradients, regressions were performed 
according to the model $y=a x^{b}$, where $y$ is phytoplankton speciesspecific biomass at the sampling date and $x$ the time-averaged (geometric mean) zooplankton abundances of days 1 (nominal seeding density) and 9. The pre-sampling time averages of zooplankton were used, because phytoplankton species biomass at the sampling dates are a time-integrated response of the period prior to sampling. Because of the factor 2 between each step of the gradient, half of the minimal values of each variable was added to the original values to avoid zeros. Regressions were accepted as significant at $P<0.05$. The exponent $b$ is an integrated measure of Daphnia or copepod impact which includes the effects of direct grazing, grazing on intermediate consumers (Protozoa) and nutrient excretion. If the plots indicated an unimodal response, a secondorder polynomial regression of the log-transformed data was also tried. The unimodal response was accepted as significant when the linear and the quadratic term had opposite signs and when both the individual terms and the entire model were significant at $P<0.05$.

After day 9, there was a major contamination of the copepod enclosures by Daphnia and a minimal copepod contamination $\left(<0.3\right.$ individuals $\left.\mathrm{l}^{-1}\right)$ of the Daphnia enclosures. Therefore, separate analyses of the two gradients were no longer meaningful. Instead, the data of both gradients were pooled and the response of phytoplankton was analysed by multiple regression analysis with stepwise variable selection (backward procedure; $F$-to-remove $=4$ ). Log algal biomass was the dependent variable and log copepod and $\log$ Daphnia abundance were the independent variables. Zooplankton abundances were the geometric means of days 13, 16, and 20, respectively. The multiple regression analysis is justified by the fact that Daphnia and copepod abundances were uncorrelated in the full data set $\left(r^{2}=0.07, P=0.22\right)$, in spite of a strong positive correlation in the copepod gradient $\left(r^{2}=0.82, P=0.0001\right)$.

\section{Results}

Time course

The temporal development of plankton communities within the mesocosms fell into two periods. Until day 9, phytoplankton species which had been detected at the start either increased or decreased in abundance, depending on experimental conditions. After day 9, several of these species (Ceratium hirundinella, Dinobryon sociale) formed resting stages and declined in abundance, irrespective of the experimental treatment. At the same time, initially undetectable species became abundant, particularly gelatinous green algae such as Pandorina morum, Paulschulzia pseudovolvox, and Nephrocytium limneticum. At day 20, algal growth was detected on the enclosure walls, and benthic, filamentous algae (Mougeotia sp.) appeared in the plankton and indicated some degeneration of the experiments.

Figure 1 shows the time course of three representative phytoplankton taxa, representing the nanoplankton, the microplankton and the gelatinous algae. The nanoplanktonic diatom Stephanodiscus parvus $(6 \mu \mathrm{m}$ diameter, $60 \mu^{3}$ volume) decreased strongly in the Daphnia gradient and the decrease was more pronounced when Daphnia densities were higher. In the copepod treatments and in the controls, they increased during the first phase of the experiments and then decreased. Other nanoplankton behaved similarly. $C$. hirundinella is one of the largest unicellular phytoflagellates $\left(150 \mu \mathrm{m}\right.$ length, 45,000 $\mu^{3}$ volume) in freshwaters. It declined in the copepod

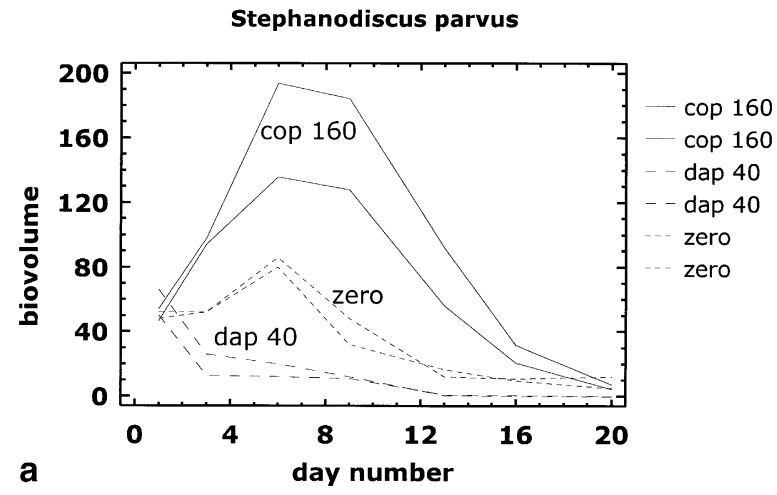

Ceratium hirundinella

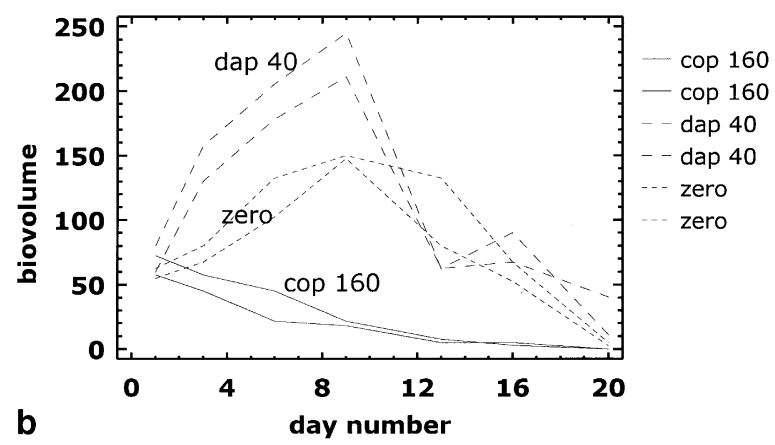

Sphaerocystis schroeteri

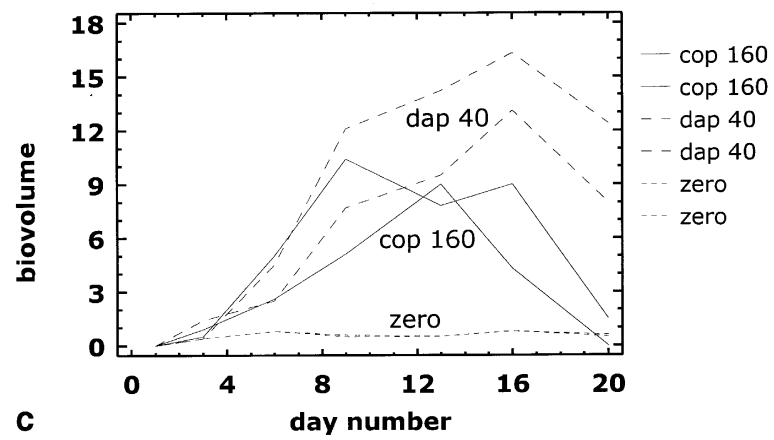

Fig. 1 Time series of three representative phytoplankton taxa shown for the highest zooplankton gradients and for the controls; phytoplankton biovolume in $10^{3}{\mu \mathrm{m}^{3}}^{\mathrm{ml}^{-1}}$; a Stephanodiscus parvus, b Ceratium hirundinella, c Sphaerocystis schroeteri. dap Daphnia, cop copepod

treatments and increased during the first phase in the Daphnia treatments. After day 9, most of the vegetative cells were converted into cysts in all treatments which lead to a drastic population decrease. The gelatinous green alga Sphaerocystis schroeteri (colony diameter $45 \mu \mathrm{m}$, volume $47,700 \mu \mathrm{m}^{3}$ ) remained at a constant, low level in the controls and increased both in the higher Daphnia and in the copepod treatments until the middle of phase 2. Then, it became partially replaced by other gelatinous green algae (Pandorina morum, Paulschulzia pseudovolvox, $N$. limneticum) 
Table 1 Impact of zooplankton type on phytoplankton bulk variables and individual taxa (arranged by colony size) measured by coefficient $b$ in a regression model $y=a x^{b}$, where $y$ is the phytoplankton variable on day 9 (chlorophyll in $\mu \mathrm{g}^{-1}$, primary production in $\mu \mathrm{g} \mathrm{C}^{-1}$ day $^{-1}$, total phytoplankton and species biomass in $10^{3} \mu \mathrm{m}^{3} \mathrm{ml}^{-1}$ ) and $x$ is the geometric mean of zooplankton seeding density and measured zooplankton density on day 9 (individuals $1^{-1}$ ). AI Assimilation index, $P / B$ production/ biomass

\begin{tabular}{|c|c|c|c|c|c|}
\hline \multirow[t]{2}{*}{ Phytoplankton variable } & \multirow{2}{*}{$\begin{array}{l}\text { Particle size } \\
\text { cell/colony } \mu \mathrm{m}^{3}\end{array}$} & \multicolumn{2}{|l|}{ Copepods } & \multicolumn{2}{|l|}{ Daphnia } \\
\hline & & $b$ & $r^{2}$ & $b$ & $r^{2}$ \\
\hline \multicolumn{6}{|l|}{ Summary variables } \\
\hline Synechococcus & 0.5 & $-0.54 \pm 0.13$ & $0.64 * * *$ & $-0.27 \pm 0.07$ & $0.60 * *$ \\
\hline Unidentified nanoflagellates & 33 & $0.51 \pm 0.10$ & $0.72 * * *$ & $-0.58 \pm 0.09$ & $0.81 * * *$ \\
\hline Stephanodiscus parvus & 60 & $0.38 \pm 0.06$ & $0.80 * * *$ & $-0.38 \pm 0.08$ & $0.72 * * *$ \\
\hline Rhodomonas minuta & 65 & $0.69 \pm 0.12$ & $0.76^{* * *}$ & $-0.65 \pm 0.15$ & $0.66^{* *}$ \\
\hline CYAN II & $3.5 / 96$ & $-1.09 \pm 0.20$ & $0.74 * * *$ & $-0.01 \pm 0.06$ & $0.004 \mathrm{NS}$ \\
\hline Cryptomonas sp. & 1,200 & $0.53 \pm 0.08$ & $0.82 * * *$ & $-0.40 \pm 0.10$ & $0.70 * * *$ \\
\hline Cryptomonas roster & 4,000 & $-0.54 \pm 0.09$ & $0.79 * * *$ & $-0.34 \pm 0.09$ & $0.59 * *$ \\
\hline Quadrigula pfitzeri & 6,800 & $0.93 \pm 0.24$ & $0.60 * *$ & $0.52 \pm 0.18$ & $0.45^{*}$ \\
\hline Peridinium bipes & 18,000 & $-0.55 \pm 0.08$ & $0.81 * * *$ & $0.20 \pm 0.05$ & $0.59 * *$ \\
\hline Ceratium hirundinella & 45,000 & $-0.59 \pm 0.09$ & $0.80 * * *$ & $0.14 \pm 0.03$ & $0.76 * * *$ \\
\hline Sphaerocystis schroeteri & $45 / 47,700$ & $0.69 \pm 0.09$ & $0.84 * * *$ & $0.76 \pm 0.11$ & $0.82 * * *$ \\
\hline Microcystis sp. & $8 / 141,000$ & $-1.23 \pm 0.19$ & $0.81 * * *$ & $0.41 \pm 0.05$ & $0.88 * * * *$ \\
\hline Dinobryon sociale & $175 / 165,000$ & $-0.35 \pm 0.05$ & $0.85 * * *$ & $-0.27 \pm 0.08$ & $0.51 * *$ \\
\hline Anabaena flos-aquae & $35 / 220,000$ & $-1.07 \pm 0.11$ & $0.90 * * * *$ & $0.40 \pm 0.10$ & $0.60 * *$ \\
\hline
\end{tabular}

$* P<0.05, * * P<0.01, * * * P<0.001, * * * * P<0.0001, N S$ not significant

a Significant second order polynomial: $\log ^{10} \mathrm{AI}=0.96+0.85 \log ^{10} C-0.39\left(\log ^{10} C\right)^{2}$, where $C$ is copepod abundance; $r^{2}=0.77 ; P<0.01$

At the beginning of the experiments, zooplankton declined in density. Nevertheless, the gradients between low- and high-density treatments were maintained, as can be seen from the tight correlations between actual animal densities on day 9 ( $C_{9}$ for copepods without nauplii, $D_{9}$ for Daphnia; in individuals $1^{-1}$ ) and nominal seeding densities $\left(C_{0}, D_{0}\right): C_{9}=1.49 C_{0}{ }^{0.74} ; r^{2}=0.95, P<0.0001$ and $D_{9}=1.41 D_{0}^{0.71} ; r^{2}=0.76, P<0.001$

Mortality was stronger in the high density treatments, as can be seen from the exponents $<1$. Calanoid copepods (Eudiaptomus gracilis, E. gracilioides) made up $>50 \%$ of the copepod community on day 9 in most enclosures. Cyclopoid copepods were represented by Mesocyclops leuckarti, Diacyclops bicuspidatus, and Thermocyclops oithonoides. There was no trend in the relative share of calanoids along the copepod gradient $\left(r^{2}=0.03\right)$. Contamination by other zooplankton taxa was still negligible on day 9.

After day 9, zooplankton abundances started to increase again. Final densities on day $20\left(C_{20}, D_{20}\right)$ were still positively correlated to seeding densities: $C_{20}=0.94 C_{0}{ }^{1.03} ; \quad r^{2}=0.57, \quad P<0.01$ and $D_{20}=0.12 D_{0}{ }^{1.64}$; $r^{2}=0.83, P<0.0001$.

Within the copepod community, cyclopoids became gradually dominant and by day 20 , calanoids contributed only $5-35 \%$ to total copepod abundance, with a marginal- ly significant decreasing trend along the density gradient $\left(r^{2}=0.32, P<0.05\right)$. Copepod contamination of the Daphnia gradients was still negligible $\left(<0.3\right.$ individuals $\left.1^{-1}\right)$ while there was a conspicuous Daphnia contamination of the copepod gradient. Daphnia density in the copepod gradient increased linearly with copepod seeding density: $D_{20}=0.18 C_{0}{ }^{0.998} ; r^{2}=0.85, P<0.0001$

This linear dependence seems to indicate that contamination did not result from a spill from outside the enclosures, but from Daphnia eggs or individuals not killed by the bubbling when the copepod inoculum was prepared. The higher the seeding density of copepods, the higher was the volume of the inoculum and, therefore, probably the number of surviving Daphnia eggs. Contamination by other metazoans (other cladoceran genera and rotifers) was negligible throughout the range of treatments.

Phytoplankton response to single zooplankton functional groups

Most of the phytoplankton summary variables showed little or insignificant responses to the experimental treatment (Table 1). The biomass measures varied within relatively narrow ranges, biovolume ca. $400-750 \times 10^{3} \mu^{3}$ 

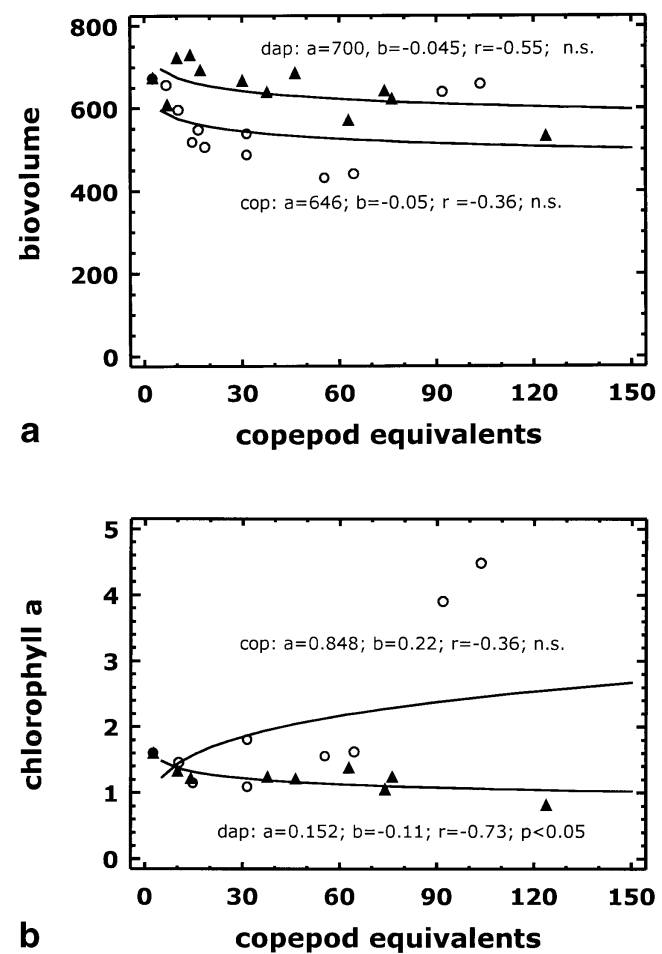

Fig. 2 Phytoplankton bulk biomass on 17 August (day 9) as a function of zooplankton density (individuals $1^{-1}$, expressed in cop equivalents, geometric mean of seeding density and measured density on day 9); $\boldsymbol{\Delta}$ dap gradient, $\bigcirc$ cop gradient; a biovolume in $10^{3} \mu \mathrm{m}^{3} \mathrm{ml}^{-1}$, b chlorophyll a in $\mu \mathrm{g} \mathrm{l^{-1 }}$. For abbreviations, see Fig. 1

$\mathrm{ml}^{-1}$, chlorophyll a ca $1-2 \mu \mathrm{g} \mathrm{l^{-1 }}$, except for the two highest copepod treatments which exceeded the other values by more than twofold (Fig. 2). Similarly, primary productivity showed no significant trends and varied between ca. 25-50 $\mathrm{mg} \mathrm{C}^{-1}$ day $^{-1}$ (Fig. 3). Measures of specific activity (assimilation index, $\mathrm{P} / \mathrm{B}$ ratio) also showed little variability. The P/B ratio increased significantly with copepod density and insignificantly with Daphnia density. The assimilation index increased significantly with Daphnia density and showed a significantly unimodal response to copepod density.

The phytoplankton response at the species level was much more pronounced (Fig. 4, Table 1). Fifteen species of nano- and microphytoplankton were abundant enough to provide reliable counts for the analysis of the Utermöhl samples. Three picophytoplankton categories were identified and counted in fluorescence microscope samples: (1) solitary Synechococcus spp. (0.5 $\mu^{3}$ cell volume), (2) CYAN I which were unidentified gelatinous colonies $\left(0.65 \mu^{3}\right.$ cell volume), and (3) CYAN II which were larger cells $\left(3.5 \mu \mathrm{m}^{3}\right)$ which formed non-gelatinous aggregates of highly variable cell numbers (four cell aggregates were dominant). For eight species, the responses to Daphnia and to copepods had opposing signs. In no case was a significantly unimodal response found.

Synechococcus responded negatively in both zooplankton gradients, CYAN I and CYAN II responded negatively to copepod density and neutrally to Daphnia
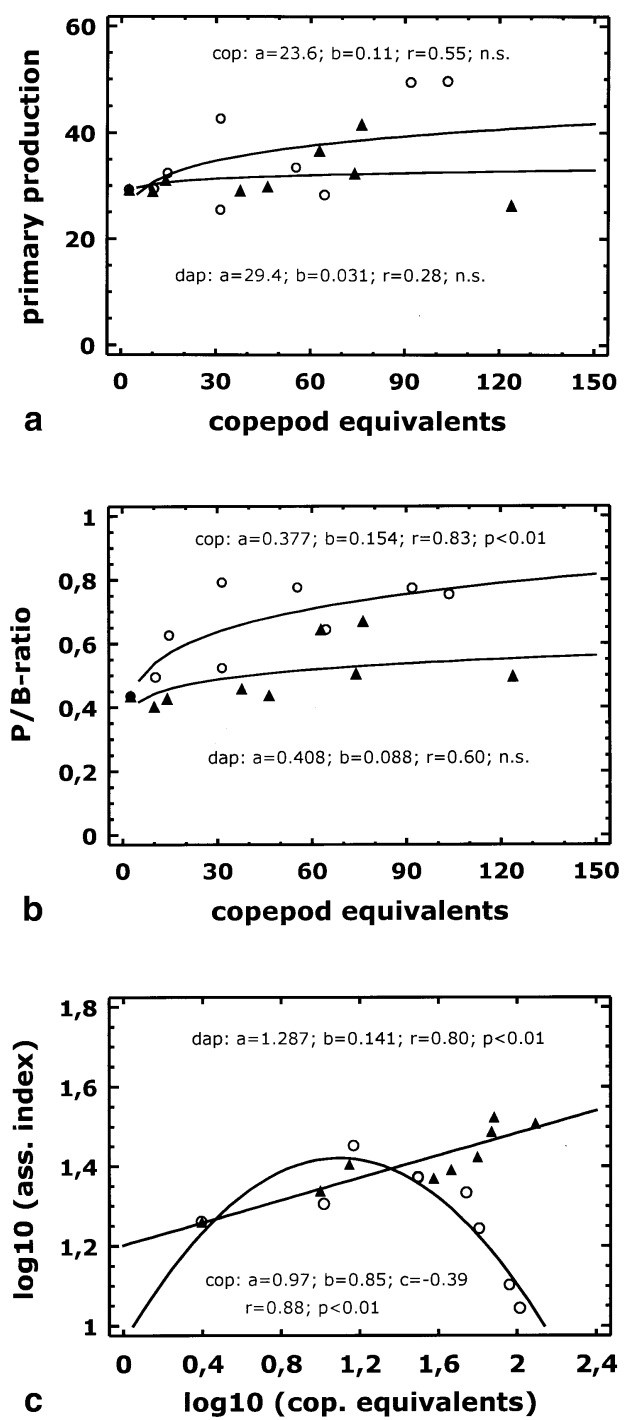

Fig. 3 Phytoplankton activity parameters on 17 August (day 9) as a function of zooplankton density (individuals $1^{-1}$; expressed in cop equivalents, geometric mean of seeding density and measured density on day 9); $\boldsymbol{\Delta}$ dap gradient, $\bigcirc$ cop gradient; a primary production in $\mu \mathrm{g} \mathrm{C} 1^{-1}$ day $^{-1}$, b productivity/biomass $(P / B)$ ratio, $\mathbf{c}$ assimilation index in $\mu \mathrm{g} C \mu \mathrm{g}$ chlorophyll $\mathrm{C}^{-1} \mathrm{day}^{-1}$. For other abbreviations, see Fig. 1

density. Eukaryotic algae from $30-$ to $3,000-\mu \mathrm{m}^{3}$ effective particle size declined with Daphnia density and increased with copepod density. Among them, the diatom Stephanodis parvus and small, unidentified flagellates were dominant components in the high copepod treatments and important ones in the controls and the low treatments of both zooplankton gradients. The flagellates Rhodomonas minuta and Cryptomonas sp. were rare in all enclosures.

The size range $3,600-4,000 \mu \mathrm{m}^{3}$ appeared to be a transition zone. Algae of that size were either negatively impacted by both types of zooplankton (the amoeboid chrysophyte Rhizochrysis sp. and the flagellate Cryptomonas rostratiformis) or they showed a negative response 
Fig. 4 Response of phytoplankton single-species biovolume $\left(10^{3} \mu \mathrm{m}^{3} \mathrm{ml}^{-1}\right)$ on day 9 on zooplankton density (individuals $1^{-1}$; geometric mean of seeding density and measured density on day 9); $\boldsymbol{\Delta}$ dap gradient, $\bigcirc$ cop gradient; $\mathbf{a}$ Stephanodiscus parvus; $\mathbf{b} C$. hirundinella, c Dinobryon sociale, d Sphaerocystis schroeteri. For other abbreviations, see Fig. 1
Stephanodiscus parvus

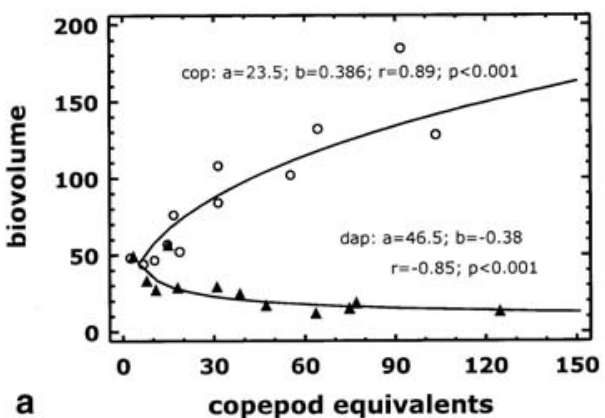

Dinobryon sociale

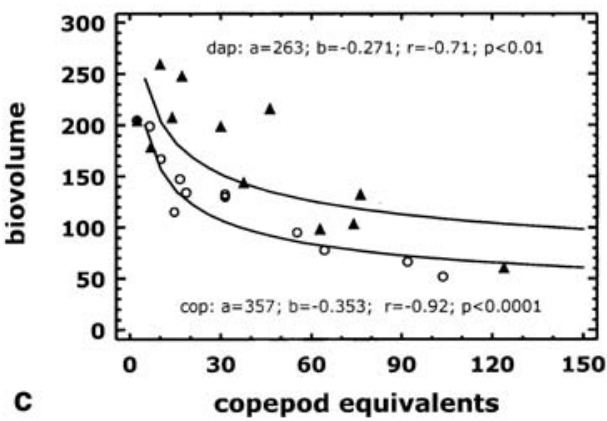

Ceratium hirundinella

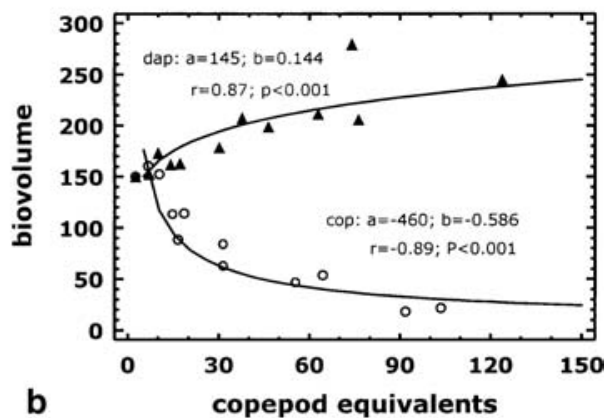

Sphaerocystis schroeteri

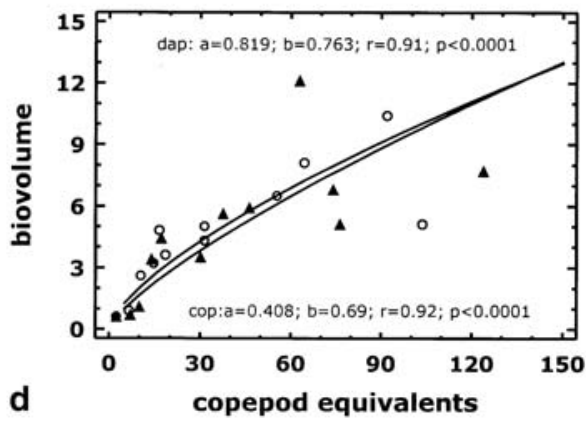

Table 2 Final models selected from a multiple regression of phytoplankton biomass $\left(10^{3} \mu \mathrm{m}^{3} \mathrm{ml}^{-1}\right)$ on copepod density, Daphnia density and the product of both zooplankton densities

\begin{tabular}{|c|c|c|c|c|c|}
\hline Dependent variable & Significant independent variable & $a$ & $b$ & $r^{2}$ & $P$ \\
\hline Total phytoplankton & Copepods $\times$ Daphnia & $188.4 \pm 10.4$ & $-0.048 \pm 0.014$ & 0.37 & 0.0022 \\
\hline Small phytoplankton & Daphnia & $89.2 \pm 9.98$ & $-1.13 \pm 0.39$ & 0.28 & 0.0092 \\
\hline Large phytoplankton & Copepods & $98.3 \pm 10.7$ & $-0.92 \pm 0.26$ & 0.38 & 0.0019 \\
\hline
\end{tabular}

Table 3 Multiple regressions of $\log ^{10}$ phytoplankton species biovolume on day $20\left(10^{3} \mu \mathrm{m}^{3}\right.$ $\mathrm{ml}^{-1}$ ) on $\log ^{10}$ copepod $(C)$ and $\log ^{10}$ Daphnia $(D)$ abundance (geometric mean of days 13, 16, 20 ; individuals $1^{-1}$ ); only final model after stepwise variable selection presented

\begin{tabular}{lcll}
\hline Species & Colony size $\left(\mu \mathrm{m}^{3}\right)$ & Equation & $r^{2}$ \\
\hline Total biomass & & $B=188-0.155 D \times C^{\mathrm{a}}$ & $0.35^{* *}$ \\
Unidentified nanoflagellates & 33 & $0.67+0.25 \log C-0.52 \log D$ & $0.70^{* * * *}$ \\
Chrysochromulina p. & 45 & $0.50+0.11 \log C-0.26 \log D$ & $0.52^{* * *}$ \\
Stephanodiscus parvus & 60 & $0.59+0.22 \log C-0.69 \log D$ & $0.46^{* *}$ \\
Gymnodinium sp. & 240 & $0.09+0.24 \log C$ & $0.34^{*}$ \\
Nitzschia acicularis & 250 & $1.17-0.26 \log D$ & $0.23^{*}$ \\
Cyclotella sp. & 480 & $0.53-0.56 \log D$ & $0.38^{* *}$ \\
Cryptomonas sp. & 1,200 & $0.68+0.19 \log C-0.39 \log D$ & $0.56^{* * *}$ \\
Rhizochrysis sp. & 3,900 & $1.69-0.56 \log D$ & $0.63^{* * * *}$ \\
Pandorina morum & 10,800 & No significant model & \\
Peridinium bipes & 18,000 & No significant model & \\
Anabaena planktonica & 45,000 & No significant model & \\
Sphaerocystis schroeteri & 47,700 & $0.80-0.23 \log C+0.18 \log D$ & $0.56^{* * *}$ \\
Paulschulzia pseudovolvox & 110,000 & $-0.37+0.60 \log D$ & $0.63 * * *$ \\
Microcystis sp. & 141,000 & $1.21-0.52 \log C$ & $0.65^{* * * *}$ \\
Dinobryon sociale & 165,000 & $1.06-0.52 \log D$ & $0.41^{* *}$ \\
Anabaena flos-aquae & 220,000 & $0.83-0.25 \log C-0.49 \log D$ & $0.49^{* * *}$ \\
Mougeotia sp. & 250,000 & $0.43+0.56 \log D$ & $0.57^{* * *}$ \\
Microcystis aeruginosa & 800,000 & $0.08+0.84 \log D$ & $0.65^{* * *}$ \\
\hline P & & &
\end{tabular}

$* P<0.05, * * P<0.01, * * * P<0.001, * * * * P<0.0001, N S$ not significant

a There was no correlation with a single zooplankton taxon nor a multiple one with both 
to Daphnia and an insignificant one to the copepods (the green flagellate Phacotus lenticularis and the diatom Stephanodiscus alpinus). The colonial flagellate Dinobryon sociale also showed a negative response to both zooplankton types. Its cells are small $\left(175 \mu \mathrm{m}^{3}\right)$ and the colonies are fragile and large (on average $165,000 \mu \mathrm{m}^{3}$ ). $D$. divergens was a dominant component of phytoplankton biomass in all enclosures except for the upper ends of both gradients.

Three of the four phytoplankton species impacted negatively by copepod density and favoured by Daphnia density were large $\left(>10,000 \mu^{3}\right)$ and had no gelatinous sheath (Peridinium bipes, Ceratium hirundinella, Anabaena flos-aquae), but the fourth species, the cyanobacterium Microcystis sp. does form gelatinous colonies (cell volume $8 \mu \mathrm{m}^{3}$, colony volume $141,000 \mu \mathrm{m}^{3}$ ). The large dinoflagellate $C$. hirundinella was a dominant component of phytoplankton biomass in all enclosures except for the high copepod treatments.

The gelatinous, colonial green algae Sphaerocystis schroeteri and Quadrigula pfitzeri responded positively to zooplankton density in both gradients but did not become dominant in any of the treatments.

Phytoplankton response after Daphnia invasion in copepod treatments

By day 20, there was still no response of phytoplankton biomass to Daphnia densities, but there was a negative one in the Daphnia-contaminated copepod-gradient. The multiple regression analysis of total phytoplankton biomass on Daphnia and copepod densities was not significant, but a linear regression of phytoplankton biomass on the product $D \times C$ was significant (Table 2). This indicates that only a combination of Daphnia and copepod was able to reduce total algal biomass. The response of individual taxa was qualitatively similar to the response on day 9 (Table 3). Small algae responded negatively to Daphnia density and either neutrally or positively to copepod density. The only exception was the cyanobacterium $A$. flos-aquae which responded negatively to both zooplankton types.

\section{Discussion}

The response of the phytoplankton species agrees with what is generally known abut the food spectra and feeding behaviour of filter-feeding cladocera and copepods (DeMott 1986, 1988; Geller and Müller 1981; Gliwicz 1980; Jürgens 1994). However, copepods and cladocerans show a much bigger overlap in food size spectra when fed by laboratory monocultures (Santer 1994; for a detailed discussion cf. Sommer et al. 2001). The positive impact of copepods on the picoplankton Synechococcus is compatible with the assumption of a four-link trophic cascade (Fig. 5): copepods suppress ciliates and thereby release
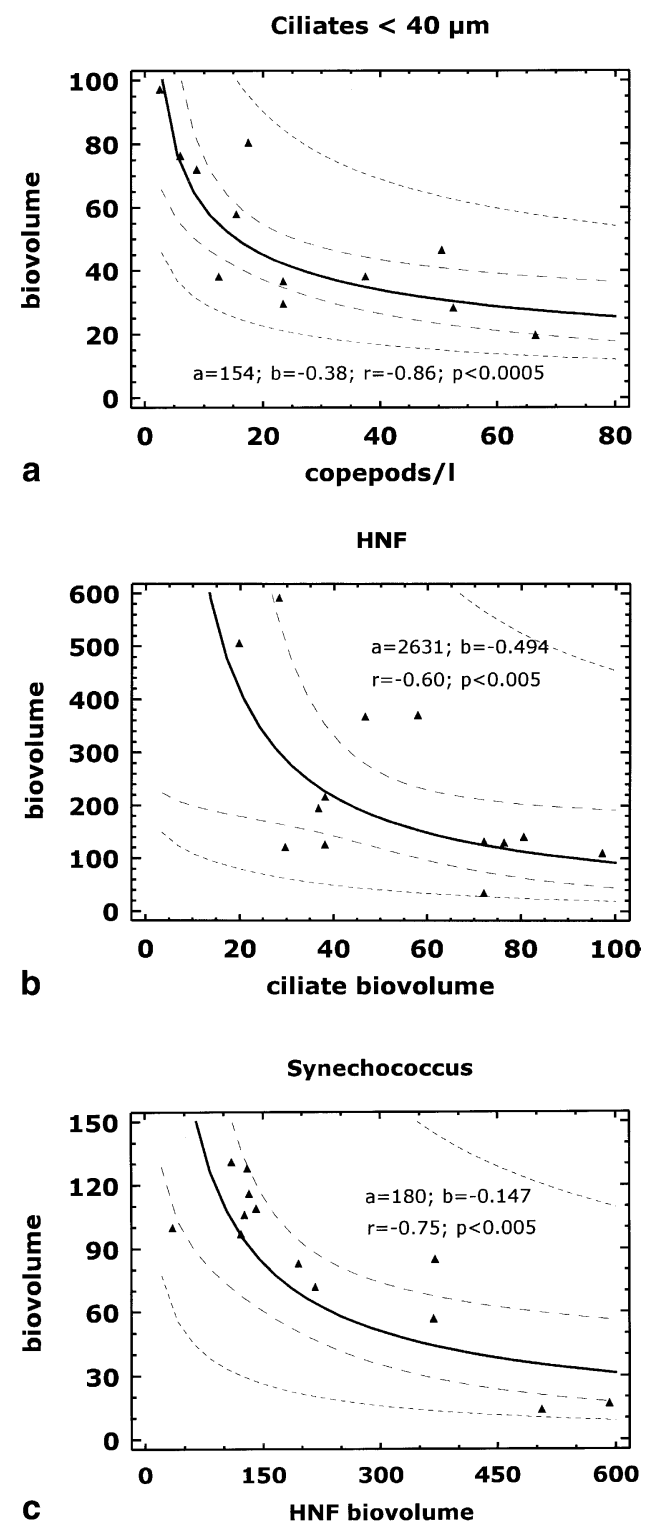

Fig. 5 Four-link tropic cascade from cop via ciliates and heterotrophic nanoflagellates to Synechococcus on day 9; all biovolumes in $10^{3} \mu^{3} \mathrm{ml}^{-1}$; - $95 \%$ confidence limits for the regression, ... 95\% prediction limits for the dependent variable; a cop-ciliate link, b ciliate-heterotrophic nanoflagellates $(H N F)$ link, c HNFSynechococcus link

heterotrophic nanoflagellates (HNF) from ciliate predation, while HNF in turn suppress Synechococcus.

Summary variables showed a much less pronounced response than individual taxa and size classes. Of course, some dampening in the response of aggregate variables would simply arise from random variability among the individual species responses (Doak et al. 1998). However, the opposing signs in the response of the majority of species suggest compensatory growth as a mechanism beyond statistical averaging. Compensatory growth might occur if incorporated nutrients are liberated from consumed algae and become available for non-consumed 
algae or if intermediate consumers (Protozoa) are suppressed.

Clear water phases induced by grazing are usually not encountered during summer when the phytoplankton consists of a wider array of size classes than during spring (Sommer et al. 1986). The usual explanations for the lack of clear water phases in summer are perfectly analogous to the standard explanation of Hairston's et al. (1960) "green world" hypothesis: successful plant defence versus predator control (in our case fish predation on mesozooplankton). In theoretical ecology, the predator control hypothesis has been extended to a linear food chain model (Oksanen et al 1981) where only the top predators and even-numbered trophic levels below the top level are controlled by system productivity while oddnumbered trophic levels are controlled by their predators. Such models ignore functional differences within trophic levels and assume that in the long run there is no successful defence against consumers. Models incorporating defended and undefended functional groups within trophic levels (Abrams 1993; Hulot et al. 2000) have led to substantially different and more realistic predictions. Our results support the general idea of functional differentiation within trophic levels, while differing in some details from Hulot's model. The Hulot model uses two categories of phytoplankton, unprotected ones ( $<35 \mu \mathrm{m}$ and without gelatinous cover) and protected ones ( $>35 \mu \mathrm{m}$ or gelatinous) and two categories of herbivorous zooplankton, small (rotifers and copepod nauplii) and large (cadocerans, adult copepods, late copepodite stages). In the model, small herbivores feed only on unprotected phytoplankton while large ones feed on both categories of phytoplankton. While the functional differentiation of phytoplankton agrees with our result, the two different groups of large herbivores in our experiments suppressed complementary parts of the phytopankton size spectrum.

The contrast between the phytoplankton response before and after the contamination of the copepod gradient permits some input to the ongoing debate about the role of biodiversity for ecosystem functions and properties (Loreau 2000; McCann 2000). There is an increasing tendency to consider functional diversity more important than species number. Our results support this tendency: it was the complementary functional diversity of Daphnia and copepods which permitted a substantial reduction of phytoplankton biomass, not the species number per se. The current discussion about the role of biodiversity has focussed on the response variables productivity, remineralisation and stability (e.g. Naeem and Li 1997; Yachi and Loreau 1999). Generalising from our results, we propose two hypotheses concerning the role of functional diversity for top-down and bottom-up control:

1. Functional diversity at the higher level increases the probability of top-down control of total biomass at the next lower level.
2. Functional diversity at the lower trophic level increases the probability of successful defence against topdown control.

Acknowledgements The experiments were sponsored by the Deutsche Forschungsgemeinschaft. Technical support by the staff of the Institut für Meereskunde at Kiel and the Max-PlanckInstitute of Limnology at Plön is gratefully acknowledged.

\section{References}

Abrams PA (1993) Effect of increased productivity on the abundance of trophic levels. Am Nat 141:351-371

Adrian R, Schneider-Olt B (1999) Top-down effects of crustacean zooplankton on pelagic microorganisms in a mesotrophic lake. J Plankton Res 21:2175-2190

Bautista B, Harris RP, Tranter PRG, Harbour D (1992) In situ copepod feeding and grazing rates during a spring bloom dominated by Phaeocystis sp. in the English Channel. J Plankton Res 14:691-703

Bottrell HH, et al. (1976) A review of some problems in zooplankton production studies. Norw J Zool 24:419-456

Burns CW, Schallenberg M (1996) Relative impact of cladocerans, copepods and nutrients on the microbial food web of a mesotrophic lake. J Plankton Res 18:683-714

Carpenter SR, Kitchell JF, Hodgson DR (1985) Cascading trophic interactions and lake productivity. BioScience35:634-639

DeMott WR (1986) The role of taste in food selection by freshwater zooplankton. Oecologia 69:334-340

DeMott WR (1988) Discrimination between algae and artificial particles by freshwater and marine copepods. Limnol Oceanogr 33:397-408

Doak DF, Bigger D, Harding EK, Marvier MA, O'malley RE, Thomson E (1998) The statistical inevitability of stabilitydiversity relationships in community ecology. Am Nat $151: 264-276$

Fussmann G (1996) Die Rolle der Rotatorien im Pelagial eines mesotrophen Sees durch Bottom-up und Top-down Prozesse: Freilandbeobachtungen und Enclosure-Experimente. Diploma thesis. University of Kiel, Kiel

Geller W, Müller H. (1981) The filtration apparatus of cladocera: filter mesh sizes and their implications on food selectivity. Oecologia 49:316-321

Gliwicz ZM (1980) Filtering rates, food size selection, and feeding rates in cladocerans - another aspect of interspecific competition in filter-feeding zooplankton. In: Kerfoot WC (ed) Evolution and ecology of zooplankton communities. University of New England Press, Hanover, N.H., pp 282-291.

Hairston NG, Smith FE, Slobodkin LB (1960) Community structure, population control, and competition. Am Nat 94:421-425

Hillebrand H, Dürselen CD, Kischtel D, Pollingher U, Zohary T (1999) Biovolume calculations for pelagic and benthic microalgae. J Phycol 35:403-424

Hulot FD, Lacroix G, Lescher-Moutoué F, Loreau M (2000) Functional diversity governs ecosystem response to nutrient enrichment. Nature 405:340-344

Jürgens K (1994) Impact of Daphnia on planktonic microbial food webs. A review. Mar Microb Food Webs 8:295-324

Kiefer F (1978) Freilebende Copepoda. Die Binnengewässer, vol 26/2. Schweizerbarth, Stuttgart

Kleppel GS (1993) On the diet of calanoid copepods. Mar Ecol Prog Ser 99:183-195

Lampert W (1978) Climatic conditions and planktonic interactions as factors controlling the regular succession of spring algal bloom and extremely clear water in Lake Constance. Verh Int Verein Limnol 20:969-974 
Lampert W (1988) The relationships between zooplankton biomass and grazing: a review. Limnologica 19:11-20

Loreau M (2000) Biodiversity and ecosystem fuctioning: recent theoretical advances. Oikos 91:3-17

McCann KS (2000) The diversity-stability debate. Nature 405:233

Naeem S, Li S (1997) Biodiversity enhances ecosystem reliability. Nature 390:507-509

Nalewajko C (1966) Dry weight, ash and volume data for some freshwater planktonic algae. J Fish Res Bd Can 23:1285-1287

Oksanen L, Fretwell SD, Arruda J, Niemela P (1981) Exploitation ecosystems in gradients of primary productivity. Am Nat 118:240-261

Pace ML, Cole JJ, Carpenter SR, Kitchell JF (1999) Trophic cascades revealed in diverse ecosystems. Trends Ecol Evol $14: 483-488$

Porter KG (1976) Enhancement of algal growth and productivity by grazing zooplankton. Science 192:1332-1334.

Porter KG, Feig YS (1980) The use of DAPI for identifying and counting aquatic microflora. Limnol Oceanogr 25:943-947

Power ME (1992) Top down and bottom up forces in food webs: do plants have primacy? Ecology 73:733-746

Santer B (1990) Lebenszyklusstrategien cyclopoider Copepoden. $\mathrm{PhD}$ thesis. University of Kiel, Kiel

Santer B (1994) Influences of food type and concentration on the development of Eudiaptomus gracilis and implications for the interactions between calanoid and cyclopoid copepods. Arch Hydrobiol 131:141-159

Shapiro J, Wright DI (1984) Lake restoration by biomanipulation: Round Lake, Minnesota, the first two years. Freshwater Biol $14: 371-383$
Sommer F, Stibor H, Sommer U, Velimirov B (2000) Grazing by mesozooplankton from Kiel Bight, Baltic Sea, on different sized algae and natural size fractions. Mar Ecol Prog Ser 199:43-53

Sommer U, Stibor H (2002) Copepoda - Cladocera - Tunicata: the role of three major mesozooplankton groups in pelagic food webs. Ecol Res 17:161-174

Sommer U, Gliwicz ZM, Lampert W, Duncan A (1986) The PEGmodel of seasonal succession of planktonic events in lakes. Arch Hydrobiol 106:433-471

Sommer U, Sommer F, Santer B, Jamieson C, Boersma M, Becker C, Hansen T (2001) Complementary impact of copepods and cladocerans on phytoplankton. Ecol Lett 4:545-550

Steemann-Nielsen E (1952) The use of radioactive carbon (C-14) for measuring organic production in the sea. J Conserv Int Explor Mer 18:117-140

Sterner RW (1989) The role of grazers in phytoplankton succession. In: Sommer U (ed) Plankton ecology. Succession in plankton communities. Springer, Berlin Heidelberg New York, pp $107-170$

Stoecker DH, Capuzzo JM (1990) Predation on protozoa and its importance to zooplankton. J Plankton Res 12:891-908

Strong DR (1992) Are trophic cascades all wet? Differentiation and donor control in diverse ecosystems. Ecology 73:747-754

Utermöhl H (1958) Zur Vervollkommnung der quantitativen Phytoplankton Methodik. Mitt Int Verein Limnol 9:1-39

Yachi S, Loreau M (1999) Biodiversity and ecosystem productivity in a fluctuating environment: the insurance hypothesis. Proc Natl Acad Sci USA 96:1463-1468 